\title{
Impact of Financial Control Mechanisms on Profitability Performance: A Case of Manufacturing Firms in Nigeria
}

\author{
Dr. Abbas Umar Ibrahim*, Abu Martins Mustapha \\ Department of Business Administration, Nile University of Nigeria, Abuja, Nigeria \\ *Corresponding Author: Dr. Abbas Umar Ibrahim, Department of Business Administration, Nile \\ University of Nigeria, Abuja, Nigeria
}

\begin{abstract}
Financial control function has become an issue of paramount concern for every firm that strives to achieve profitability, growth and survival in a dynamic business environment. This is because a quality financial control system is essentially a hallmark for efficiency and effectiveness in operations which snowball to superior performances. This study investigated the impact of financial control mechanisms on the profitability performance of Nigerian manufacturing firms and seeks to suggest valuable recommendations which can improve better performances in the sector. The study population was 275 and a sample size of 125 drawn from the population using simple random sampling technique. Data were collected by means of questionnaire (101 returned out of 125 distributed) which was analyzed using SPSS. Descriptive and inferential statistical techniques were adopted using Pearson's Product Moment Correlation to establish the significance of the relationship between the variables and the single t-test to test the other hypotheses. Findings revealed a significant positive relationship between financial control mechanisms and firms' profitability performance. It was recommended that manufacturing firms should continuously improve on their of application financial control techniques through the selection of suitable and consistent control mechanisms.
\end{abstract}

Keywords: Financial Control, Profitability, Organizational Efficiency, Manufacturing, Firms

\section{INTRODUCTION}

Over the years, the success of manufacturing industries has attracted the attention of academicians, managers and other professionals. This is cardinal because identifying the key success factors of manufacturing firms' profitability will allow for designing of tailored policies and strategies that will significantly improve the overall performance of the sector. (Siyanbola, 2013). In spite of the seeming increased attention in the running of the manufacturing sector in Nigeria, together with the institutional support to sustain this sector, performance in some have appeared to be below expectations. (Adebayo and Onyeiwu, 2018)

Profitability is a concept that has received serious attention all over the globe, this is because the growth and development of any profit-oriented business enterprise depend on its ability to remain profitable at all times, even in the period of the visible current financial crunch of the world economy. Siyanbola and Raji, (2013) stated that profitability has attracted considerable importance in finance and accounting literature. Also, Malik, (2011), have emphasized profitability has been one of the primary objectives of financial management and control which is to maximize the owners' wealth. Hence, profitability is cardinal determinants of performance for wealth maximization. A business that is not profitable cannot survive in the long run. Furthermore, the current intensity of competition in the business environment has made running a successful business a function of its ability to be profitable and survive. Therefore, the ultimate goal of a business is to earn enough profit to ensure sustainability in prevailing market conditions. (Adebayo and Onyeiwu, 2018).

Moreover, the effectiveness and efficiency of a firm's utilization of resource can be measured by its profitability. Profit is a key factor. This is because the more profit reflects a more effective and efficient utilization of resources and vice versa. Low profitability can slow the rate at which a firm progresses and certain obligations and at times target might not be met (Adebayo and Onyeiwu, 2018). It is, therefore, to achieve effectiveness and efficiency that Harley and Emery, (2016) concluded that a detailed control over a number of parameters is required to access the financial 
condition and situation of the business in detail. They also recommended that to organize an effective system of financial control, management should delegate their power to the subordinate who is conversant with facts in cost management.

The application of these financial control mechanisms has generated a lot of argument (with some scholars arguing in favor of while others against) it use. This is because, while financial control has been adopted by the world of management as a tool for achieving organizational performance (Ajonbadi et al, 2014) others have viewed the effect as a hindrance to free workflow process. The high rate of corporate failure and low contribution to GDP could be attributed to the poor performance of the manufacturing sector due to lack of adequate financial planning and control. It has been mentioned that some manufacturing firms do not have a financial plan talk less of a financial control framework. This absence has resulted in reckless spending, wastages and fraud culminating into poor performance (Uwuigbe, et al, 2011).

In addition, the manufacturing sector in this contemporary time of globalization is inundated with myriad problems but have a bright prospect for development. There is therefore the need for the application of financial control mechanisms to solve some of these problems in order to realize the anticipated prospects for growth and development.

Hence, the aim of this study is to empirically evaluate the effect of financial control mechanisms on the profitability performance of manufacturing firms in Nigeria. While the specific objectives are to:

- Investigate the relationship between the use of financial control mechanisms and profitability in manufacturing firms in Nigeria.

- Establish some of the financial control mechanisms that significantly contribute to the profitability performance of manufacturing firms in Nigeria.

- Suggest some measures that will enhance the effectiveness of the use of financial control mechanisms for better profitability performance of the manufacturing firms in Nigeria.

Therefore this study seeks to address three research questions/ hypothesis:

- To what extent do financial control mechanisms affect firms' profitability performance?

- How do financial control mechanisms contribute to firms' profitability?

- What are the measures to enhance and mitigate the problem(s) associated with the use of financial control mechanisms for firms' profitability performance?

\section{Literature REVIEW: Conceptual AND THEORETICAL FrameWORK}

After the comprehensive design and implementation of strategies and plans, it is essential that they are systematically reviewed, evaluated and controlled. Controls are the task to ensure that strategies and plans are executed as agreed and/or adjustments are effected where it becomes necessary. Control has, therefore, become a vital function of management. Control could be seen as a 'system' as viewed by the system theorist which is likened to a system where feedback information is obtained, possible adjustment made to the system to attain its goal. Control could be a 'management function' which plan and take corrective action where necessary or a 'process' that ensures that anticipated results are achieved (Uwuigbe, et al, 2011: and Harley and Emery, 2016).

The framework for control consists of four distinct parts namely: the setting of standards, measuring performance, comparing the performance against standards and taking appropriate corrective action when and where necessary ( Kotov 2012; and Ajonbadi et al, 2014). However, some researchers have viewed control as influence exercised on the subordinates to induce compliance with organizational goals (Levine, 2012; and Osadchy and Akhmetshin, 2015).

Financial control has been construed as the analysis of a firm's actual results, compared to its short, medium and long-term objectives and business plans. These analyses require adjustment processes to ensure that business plans are being adhered to and that they are also amended in the event of any anomalies, irregularities or unpredicted circumstances. The need for control as opined by Prempeh, (2015) is that organizations operate in an imperfect world where strategies do not always work as planned, hence control becomes inevitable because of the dynamism in the environment and behavioral factors associated with employees' motivation. Also it therefore, becomes essential that 
control measures are incorporated in business strategies to accomplish planned performance. Financial control is a management tool that allows for quick identification and elimination of factors that are not conducive for efficient attainment of goals. These tools could be budgetary control, improved financial reporting, reducing administrative cost reduction and improving efficiency, eliminating or managing unnecessary business risk. (Becker, et al. 2011; and McCrindell, 2015).

The concept of profitability has also been a source of concern to managers of firms, this is because of present performance and the uncertainty that lies with the future (Agbaje and Funson, 2018). Sometimes the two terms; profit and profitability could be used interchangeably. However, in a real sense, there are differences between the two words. Whereas the word Profit is an absolute concept, profitability is a comparative term. Profit refers to the total income/sales earned net of total expenses incurred by the firm during a specified period of time, while profitability is a term that relates to how efficient the operations of the firm is. It is the ability of the firm to make profit on sales, which is to get a sufficient return on the capital, land and labor used in the business operations. There are three widely known determine of profitability: Return on Investment (ROI), Return on Asset (ROA) and Return on Equity (ROE) Chowdhury et al., (2018). However, there are divergent opinions among scholars on the supremacy of one measure over the other as a good measurement of profitability. Levine, (2012) posits that the firm's profitability has a direct relationship with financial development and economic growth in both developed and developing countries.

\subsection{Theoretical Review: Rent Theory of Profitability}

The theoretical framework underpinning this study is the rent theory of profitability, which was first propounded by an American Economist, Walker. This was founded on the ideas of Senior and renowned economist J.S. Mill. This theory of profit states that profit is the 'rent' of superior entrepreneur over marginal earnings of a less efficient entrepreneur. To them, there was a high level of resemblance between the two terms: rent and profit. Rent is the compensation for the use of land while profit is the return for the ability deployed by the entrepreneur. Just as land differs in terms of fertility, so also, entrepreneurs differ in their abilities. According to the critics of this theory, there cannot be a perfect likeness between these two terms; rent and profit. While rent is generally positive and in rare cases cannot be zero, when entrepreneurs suffer loses, profit can be negative. The theory explains profit as differential surplus rather than a reward for an entrepreneur. (Hunt and Lautzenheiser, 2011).

\section{EMPIRICAL EVIDENCE}

Manufacturing firms are aware of the financial control system (Ajonbadi, et al. 2014). In a study, Omboga et al., (2016) revealed that financial control is essential for the industry's positive performance, this could be achieved through effective cash control, cash processing and budgeting but recommended the examination of the effect of human behavior on the application of financial control mechanisms. Also, Harley and Emery, (2016) and Oyebanji, (2018) concluded that the approach of organizing the system of financial control influences not only the safety of material and financial resources but all of its financial and economic activities. A properly organized system of financial control allows not only for early detection of flaws but to take timely action to address them. Prempeh, (2015) concluded that raw materials and inventory management has a significant effect on the profitability of manufacturing firms and further suggested that other control variables should be incorporated in further studies of these variables.

Simiyu et al. (2018) and Ibrahim et al. (2017) conducted on studies of risk and financial planning practices and have established that sound financial management practices and control are components that have significant yet moderating relationship with the performances of the firm. While Maiga et al., (2018) and Mutya, (2018) concluded from the study of the interaction effect of cost control system and information technology integration that manufacturing plant could obtain the utmost financial performance and rewards from investments in activity-based cost control systems in conjunction with information technology integration. Baseweti \& Muturi, (2018) in the study 'effect of risk mitigation on the financial performance of manufacturing firms' discovered there was a significant strong positive relationship between changes in production, economic risk mitigation and financial performance. They recommended that companies should practice comprehensive risk mitigation planning to counter any likely event that might cause a business breakdown. 
Agbaje and Funson, (2018) also concluded that pragmatic policy options should be formulated in the manufacturing industry to effectively manage and prevent firm from recording fictitious revenue in order enhance performance, this is because there was a significant negative relationship between financial reporting fraud and profitability. Also, fraud prevention in financial statements should be sufficiently inculcated into the internal control system for the effective running of the manufacturing industries in Nigeria. Ajonibadi et al., (2014) stated that financial control in a large organization is often the responsibility of various groups like the audit committee, management committee, financial controller etc. however, this is often not the case in smaller organizations where control is the responsibility of a single manager. (Bett \& Memba, 2017). McCrindell, (2015) therefore, concluded that the purpose of any financial management and control framework is to facilitate and set boundary lines for the planning, use and accounting of resources which will impact on the profitability.

\section{RESEARCH SETTINGS}

The setting of the research is the Federal Capital Territory- Abuja and Kaduna metropolis. Abuja is the capital city of Nigeria while Kaduna city is a state capital of Kaduna state situated in the northwest region of Nigeria. Kaduna is one of the commercial nerves of the northern part of Nigeria. The cosmopolitan nature of the two cities supports industrial location. Hence Kaduna has one of the largest concentrations of different manufacturing firms besides Kano city.

Collectively, the aforementioned characteristics of Abuja and Kaduna justified the selection of this research setting. The focus here is to assess the effect of financial control mechanisms on the manufacturing firms' profitability in Nigeria, with emphasis on Abuja and Kaduna primarily because of the dearth of research in these areas.

According to the National Bureau of Statistics, the Nigerian Manufacturing sector is comprised of thirteen activities: Oil Refining; Cement; Food, Beverages and Tobacco; Textile, Apparels, and Footwears; "Wood and Wood products; Pulp Paper and Paper products; Chemical and Pharmaceutical products; Non-metallic Products,; Electrical and Electronic, Basic Metal and Iron and Steel; Motor Vehicles and Assembly; and Other Manufacturing. The sector employed about 23\% of the workforce in Nigeria". This underscores the enormous potential for contribution to the GDP and employment generation which give a good reason for the selection of the sector as a focus for this study.

\subsection{Research Method and Design}

This study adopts the survey method under the quantitative research that uses correlation to assess the relationship among the variables: financial control mechanisms and profitability performance of the manufacturing firms in Nigeria. Studies by (Creswell, 2013: and Ajonbadi et al, 2014) have also justified the use of correlation in establishing the strength of a relationship between or among two or more variables. The choice of survey method is because of the wide range of its uses in social sciences (Bryman and Bell, 2013). This allows for gathering and processing information for the purpose of examining the variables in the study. In line with the nature of this inquiry, an epistemological assumption of the research philosophy was used, by means of empirical approach as revealed in the works of Sauder et al., (2009), Sekran, (2011); Bryman, (2011) and Creswell, (2013).

\subsection{Description of Population, Sampling Technique and Sampling Size}

In a survey study, data are collected from the population. The population of this study comprises 275 staff of the selected manufacturing firms operating in Abuja and Kaduna metropolis. These firms are located in Idu Industrial layout in Abuja and Kakuri Industrial layout in Kaduna.

From the participating firms, five(5) employees from the stratified sample of the finance and accounting sections were then randomly selected as unit of analysis to elicit information on how financial control dimensions such as budgetary control, financial reporting, cost control and management of risk enhance efficiency to guarantee quality profitability performance of the firms.

\subsection{Data Collection Methods and Unit of Analysis}

The primary source of data is the questionnaire which enables the researcher to collect good and meaningful data better suited for the study in order to arrive at a dependable solution to the research questions. The use of financial control techniques was examined by adopting and the measurement of 
the impact of control techniques on profitability performance. To ensure the validity of this instrument, it was subjected to criticisms and review by specialists in the areas of management sciences. Also, a pilot review was earlier conducted. The reliability of the instrument was obtained through a test-retest technique to analyze the data was collected. This was established with the use of Cronbach's alpha technique. It compared the reliability result with the standard value alpha of 0.7 as advocated by Cronbach and it was found to be within the acceptable range.

A total of 125 copies of the questionnaires were administered on the selected sample, 101 were completed and returned. These formed the basis of analysis. The respondents who could not return their instrument cited reasons ranging from apathy, reluctance to divulge information and organizational policy on official secrecy to buttress their non-responses.

To achieve a meaningful usage from the data collected, the statistical package SPSS- Statistical Package for Social Science software was adopted. The choice of this method of analysis was informed by its extreme command as a data analysis package that can handle compound statistical procedures (Pellant, 2015). Also, it is one of the widely used packages in social sciences research. The following statistical techniques were used; descriptive statistics such as mean, mode, median, and standard deviation to measure financial control mechanisms in the responding firms. While the t-test was used to test the hypotheses. The one-sample t-test compares the mean of one variable with a known hypothesized value. Inferential statistics such as Pearson's correlation(r) was adopted to ascertain the significance of the relationship between the variables. In addition, all the statistical tests were conducted at the conventional 95\% confidence intervals (ie, significance level of 0.05 ).

\section{RESUlTS AND ANALYSES}

\subsection{Application of Financial Control Mechanisms by Nigerian Manufacturing Firms}

Table5.1. Application of Financial Control Mechanisms by Participating Firms N=101

\begin{tabular}{|l|l|l|l|l|l|l|l|}
\hline \multicolumn{9}{|c|}{ Descriptive Statistics } \\
\hline & \multicolumn{1}{|c|}{$\mathbf{N}$} & \multicolumn{1}{|c|}{ Mode } & Median & \multicolumn{2}{|c|}{ Mean } & Std. Deviation & Variance \\
\cline { 2 - 9 } & Statistic & Statistic & Statistic & Statistic & Std. Error & Statistic & Statistic \\
\hline Budgetary Control & 101 & 5 & 4 & 4.50 & .0532 & .535 & .286 \\
\hline Financial Reporting & 101 & 5 & 5 & 4.75 & .0349 & .3505 & .123 \\
\hline Cost Control & 101 & 5 & 5 & 3.74 & .0500 & .502 & .252 \\
\hline Improving Efficiency & 101 & 5 & 4 & 4.50 & .0532 & .545 & .297 \\
Fraud Detection & 101 & 5 & 5 & 4.87 & .0340 & .3421 & .117 \\
Risk Mitigation & 101 & 5 & 4 & 3.95 & .0253 & .254 & .065 \\
Quality Management & 101 & 5 & 4 & 3.78 & .0500 & .452 & .204 \\
External Audit & 101 & 5 & 4 & 4.78 & .0322 & .324 & .105 \\
Internal control & 101 & 5 & 5 & 4.21 & .0320 & 3214 & .103 \\
\hline
\end{tabular}

Source: Computerized results from SPSS (2018)

The application of financial control mechanisms was measured by examining the use of budgetary control, financial reporting, cost control, improving efficiency, fraud detection, risk mitigation, quality management, external audit, and internal control. These mechanisms were measured on a five-point Likert scale ranging from: 'strongly disagreed' (scored $=1$ ) to 'strongly agreed' (scored=5). From the above table, the report shows significant use of most of the financial control mechanisms. The reported mean values of the control range from 3.75 to 4.78 . While the standard error of the mean range from 0.320 to 0.532 which is within the acceptable range of $5 \%$ error, meaning that the opinion of the sampled respondents represents the view of the population.

\subsection{Organizational Effectiveness of Nigerian Manufacturing Firms}

\subsubsection{Hypotheses Testing}

The following hypotheses were tested:

\section{Hypothesis 1}

$\mathrm{H}_{0}$ : There is no significant relationship between the use of financial control mechanisms and manufacturing firms' profitability performance. 
Impact of Financial Control Mechanisms on Profitability Performance: A Case of Manufacturing Firms in Nigeria

$\mathrm{H}_{1}$ : There is a significant relationship between the use of financial control mechanisms and manufacturing firms' profitability performance.

Table5.2.1. Financial control and Organizational Efficiency: Pearson Product Moment Correlations Results

\begin{tabular}{|c|c|c|c|c|}
\hline \multicolumn{5}{|l|}{ Correlations } \\
\hline & & $\begin{array}{l}\text { Financial } \\
\text { Control } \\
\text { Mechanisms } \\
\end{array}$ & $\begin{array}{lr}\begin{array}{l}\text { Firm's } \\
\text { on }\end{array} & \text { Return } \\
\text { (ROA) } & \text { Assets } \\
\end{array}$ & $\begin{array}{l}\text { Firm's Return of } \\
\text { Capital } \\
\text { Employed(ROE) }\end{array}$ \\
\hline \multirow{3}{*}{$\begin{array}{l}\text { Financial } \\
\text { Control } \\
\text { Mechanisms }\end{array}$} & Pearson Correlation & 1 & $.762^{*}$ & $.768^{*}$ \\
\hline & Sig. (2-tailed) & & .028 & .026 \\
\hline & $\mathrm{N}$ & 101 & 101 & 101 \\
\hline
\end{tabular}

*Correlation is significant at the 0.05 level (2-tailed).

Source: Computerized results from SPSS (2018)

Interpretation: To establish the strength of the relationship between financial control mechanisms and the firms' profitability, the Pearson's Product Moment Correlation was used. From the Table 5.2, the result of the correlation is 0.762 for contribution to ROA and 0.768 for ROE at $5 \%(0.05)$ level of significance. One can conclude that financial control mechanisms are significantly related to profitability (Return on Assets and Return on Capital employed).

Decision: This confirmed the prediction in the alternative hypothesis that there exists a significant relationship between the uses of financial control mechanisms to achieve manufacturing firms' profitability in Nigeria.

\section{Hypothesis 2}

$\mathrm{H}_{0}$ : There is no increasing positive impact between the uses of financial control mechanisms on manufacturing firms' profitability performance.

$\mathrm{H}_{1}$ : There is an increasingly positive impact between the uses of financial control mechanisms on manufacturing firms' profitability performance.

Table5.2.2. Descriptive Statistics for Impact of Financial Control on Profitability Performance

\begin{tabular}{|l|c|c|c|c|}
\hline & $\mathbf{n}$ & Mean $(\mathbf{x})$ & Standard Deviation $(\boldsymbol{\mu})$ & Standard Error Mean \\
\hline $\begin{array}{l}\text { Does the use of financial control } \\
\text { mechanisms have an increasing } \\
\text { positive impact on firm's } \\
\text { profitability performance? }\end{array}$ & 101 & 4.34 & 0.534 & 0.053 \\
\hline
\end{tabular}

Source: Computerized results from SPSS (2018)

Table5.2.3. One Sample 't'- Test for hypothesis 2

\begin{tabular}{|c|c|c|c|c|c|c|}
\hline \multicolumn{7}{|c|}{ One-Sample Test } \\
\hline & \multicolumn{6}{|c|}{ Test Value $=0$} \\
\hline & \multirow[t]{2}{*}{$\mathbf{t}$} & \multirow[t]{2}{*}{ df } & \multirow[t]{2}{*}{$\begin{array}{l}\text { Sig. (2- } \\
\text { tailed) }\end{array}$} & \multirow[t]{2}{*}{$\begin{array}{c}\text { Mean } \\
\text { Difference }\end{array}$} & \multicolumn{2}{|c|}{$\begin{array}{l}\text { 95\% Confidence Interval of the } \\
\text { Difference }\end{array}$} \\
\hline & & & & & Lower & Upper \\
\hline $\begin{array}{l}\text { Does the use of financial control } \\
\text { mechanisms have an increasingly } \\
\text { positive impact on firm's } \\
\text { profitability performance? }\end{array}$ & 7.937 & 100 & .000 & 4.34 & 1.05 & 1.95 \\
\hline
\end{tabular}

Source: Computerized results from SPSS (2018)

The one-sample statistics shown in Table 5.2.2 revealed that there are 101 observations represented by ' $n$ ', with the mean of 4.34 and the standard deviation of 0.534 . The standard error of sampling mean is 0.053 approximately $5 \%$ which is an acceptable percentage of standard error.

Decision: Here the study seeks to establish if to accept or reject the null hypothesis. The decision rule is that where the critical ' $t$ ' value is less than the computed ' $t$ ', then reject the null hypothesis $\left(\mathrm{H}_{0}\right)$. From the table 5.2.3, the computed ' $t$ ' is 7.937 which is greater than the critical' $t$ ' of 1.660 obtained from the statistical table. Therefore reject the null hypothesis $\left(\mathrm{H}_{0}\right)$ and accept alternative hypothesis 
$\left(\mathrm{H}_{1)}\right.$ which states that there is an increasingly positive impact between the uses of financial control mechanisms on manufacturing firms' profitability performance.

Therefore one can conclude that the use of financial control mechanisms has an increasingly positive impact on the profitability performance of manufacturing firms in Nigeria.

\section{Hypothesis 3}

$\mathrm{H}_{0}$ : There is no problem(s) associated with the application of financial control mechanisms effect on firms' profitability

$\mathrm{H}_{1}$ : There is problem(s) associated with the application of financial control mechanisms' effect on firms' profitability.

Table5.2.4. Descriptive Statistics for Problems associated with Financial Control

\begin{tabular}{|l|c|c|c|c|}
\hline & n & $\begin{array}{c}\text { Mean } \\
\text { (x) }\end{array}$ & $\begin{array}{c}\text { Stamdard } \\
\text { Deviation(M) }\end{array}$ & $\begin{array}{c}\text { Standard Error } \\
\text { Mean }\end{array}$ \\
\hline $\begin{array}{l}\text { Do you think that there } \\
\text { are problems associated } \\
\begin{array}{l}\text { with the application of } \\
\text { financial control } \\
\text { mechanisms on firms' } \\
\text { profitability in Nigeria }\end{array}\end{array}$ & 101 & 1.59 & 0.354 & 0.035 \\
\hline
\end{tabular}

Source: Computerized results from SPSS (2018)

Table5.2.5. One Sample ' $t$ '- Test for hypothesis 3

\begin{tabular}{|c|c|c|c|c|c|c|}
\hline \multicolumn{7}{|c|}{ One-Sample Test } \\
\hline & \multicolumn{6}{|c|}{ Test Value $=0$} \\
\hline & \multirow[t]{2}{*}{$\mathbf{t}$} & \multirow[t]{2}{*}{ df } & \multirow[t]{2}{*}{$\begin{array}{l}\text { Sig. (2- } \\
\text { tailed) }\end{array}$} & \multirow[t]{2}{*}{$\begin{array}{c}\text { Mean } \\
\text { Difference }\end{array}$} & \multicolumn{2}{|c|}{$\begin{array}{l}\text { 95\% Confidence Interval } \\
\text { of the Difference }\end{array}$} \\
\hline & & & & & Lower & Upper \\
\hline $\begin{array}{l}\text { Do you think that there are problems } \\
\text { associated with the application of } \\
\text { financial control mechanisms on } \\
\text { firms' profitability in Nigeria }\end{array}$ & 4.354 & 100 & .000 & 1.594 & 1.45 & 1.74 \\
\hline
\end{tabular}

Source: Computerized results from SPSS (2018)

The one-sample statistics in Table 5.2.4 shows that there are 101 observations represented by ' $n$ ' with a mean value of 1.59 and a standard deviation of 0.737 . The sampling mean standard error is 0.035 approximately $4 \%$ which is an acceptable percentage of standard error.

Decision: from the above table 5.2.5, the computed ' $t$ ' from the SPSS is 4.345 which is greater than the critical' $t$ ' of 1.660 obtained from the statistical table. Where this is the case, the decision rule is to reject the null hypothesis $\left(\mathrm{H}_{0}\right)$ and accept alternative hypothesis $\mathrm{H}_{1}$.

Therefore one can conclude that there are some problems associated with the use of financial control mechanisms. These problems include knowledge gap of contemporary control issues, weaknesses in the legal and regulatory framework, attitudinal problem on the part of the control staff, problem of "shifted" responsibilities for possible failures in the system, weaknesses in the control process, lack of procedure manuals etc.

\section{DISCUSSION OF FINDINGS}

The need for financial control mechanisms has been widely accepted by the Nigerian manufacturing firms (Agbaje and Dare, 2018). Financial control is vital in every organization which requires monitoring and coordination of activities. The essence of financial control is to ensure that actual results conform to planned standards.

The problems associated with lack of control could result in a greater magnitude of loses. Hence, managers of firms need to adopt a variety of financial control techniques to wade off defiant behavior that could result in loses (Eniola and Aakinselure, 2014). The findings of this study have indicated that financial control mechanisms such as budgetary control, financial reporting, cost control, fraud detection, risk mitigation, quality management, external and internal audits are well entrenched in the manufacturing sector. This is also in support of the findings of Eniola and Akinselure, (2016); Abass, (2018); Basweti and Muturi, (2018); and Oyebanmiji. (2018). 
For the manufacturing firms, financial control provides a critical role in strategy formulation, implementation, and evaluation process. For those that have discovered the importance of financial planning, must use financial control mechanisms after implementation and for evaluation of the chosen strategy. The uniqueness of a good plan is in its inbuilt feedback and control mechanisms or systems.

In today's business environment, intense competition is the order of the day. The business context of every organization is a constantly changing environment. This environmental dynamism and competition have force business organizations to focus on how to be effective and efficient in their operations and consequently stressed out the need for performance improvement through financial control. Recession, financial crisis, lack of funding/ lean financing of manufacturing by the financial institutions have unarguably been the reason to awaken the consciousness of management coupled with the compelling need to adopt a cost reduction scheme and increase profitability through efficiency, use of budgeting, quality control to curb wastages (Selvanayaki et al, (2016); Oyebamiji, (2018); Maiga et al, (2018); and Ikrama and Ahmed, 2018).

Most of the firms used in the study that have entrenched application financial control mechanisms reported improvement in performances. The techniques varied from fraud detection, cost reduction followed by external audit, financial reporting, budgetary control, internal audit amongst others. this confirmed the findings of Kinyua et al, (2015); Koech et al, (2015); Kahando et al, (2017); Amafu and Baidu, (2018); and Simiyu and Mainin, (2018) on the determinant of manufacturing firm performance.

Chowdhury et al, (2018), attributed that working capital management through effective control is an instrument of profitability performance. This is because financial managers will be able to create value for their shareholders through the efficient management of working capital by exploiting the relationship between working capital variables and profitability in a grossly hostile internal and external environment.

Many studies have attempted to examine the role of financial control on firms' performance. Majority of their findings also reveal a positive relationship (Siwangaza, 2014; Selvanyaki et al, 2016; and Bett and Memba, 2017). To attain superlative performance, the application of financial control mechanisms is of the essence. This is because it creates responsibility and accountability (Ajombadi et al, 2014). This brought to the fore the need for the organization to be cost conscious and sensitive, as cost unmanaged could lead to low profit, losses and subsequently corporate failure. Control enables firms to secure high efficiency, better quality innovativeness, and creativity which are the hallmark for securing core competence and building a competitive advantage.

\section{CONCLUSION AND RECOMMENDATIONS}

The financial control function is paramount for every firm to adopt. This is because many studies have revealed that the application of quality financial control mechanisms brings about efficiency and effectiveness in operations that snowball to superior performances. Since, the business environment is dynamic and highly competitive therefore strategic planning is a fundamental prerequisite for survival and growth. However, planning without control is incomplete, because control ensures monitoring and evaluation of the plan.

The manufacturing sector is vital because the sector generates employment opportunity to many Nigerians even in the face of decaying infrastructure and the harsh current economic reality on the ground. The sector has contributed to the country's GDP, improving the standard of living and has served as the engine room for achieving the much desired economic transformation program, tagged as Nigeria Vision 20: 2020. To achieve this vision, the sector needs to take advantage of the cluster development strategy for manufacturing and processing industries.

The significant relationship between the variables: financial control and profitability performance of the participating firms suggest the need to extend the study beyond the manufacturing firms to other sectors of the economy in other make a meaningful contribution to the economic growth and development of the nation.

\section{REFERENCES}

[1] Adebayo I.S and Onyeiwu C. (2018), The Determinants of Profitability of Manufacturing Firms in Nigeria. International Journal of Economics, Commerce and Management, vol, vi(6) 
[2] Agbaje W.H. \& Dare F.,(2018). Dynamic Analysis of Financial Statement Fraud on Profitability of Manufacturing Firms in Nigeria. International Journal of Business and Management Review, vol. 6(2), pp. 65-81 www.eajournals.org

[3] Ajonbadi, H. A., Lawal, A.A., Badmus D.A. and Otokiti B.O.(2014). Financial Control and Organisational Performance of the Nigerian Small and Medium Enterprises(SMEs): A Catalyst for Economic Growth. American Journal of Business, Economics and Management, Vol 2(2) pp 135-143

[4] Basweti A. M. \& Muturi W.,(2018). Effects of Risk Mitigation on Financial Performance of Manufacturing Firms: A Case of Tea Factories in Kisii County-Kenya. International Journals of Academics \& Research, vol. 1(1), www.ijarke.com

[5] Becker W., Baltzer B. and Urlich P. (2011), 'Controlling as a science in Germany - Retrospective, Status Quo and Outlook', Singidunum Revija, 8 (2), pp. 40-54.

[6] Bett J. C. \& Memba F. S., (2017). Effects of Internal Control on the Financial Performance of Processing Firms in Kenya: A Case f Menengai Company. International Journal of Recent Research in Commerce, Economics and Management (IJRRCEM), vol.4 (1) pp105-115 www.paperpublications.org

[7] Chowdhury A. Y., Alam M.Z., Sultana S.\& Hamid M.K.(2018). Impact of Working Capital Management on Profitability: A Case Study on Pharmaceutical Companies of Bangladesh. Journal of Economics, Business and Management, vol. 6(1)

[8] Eniola O. J. \& Aakinselure O. P., (2016), Effect of Internal Control on Financial Performance of Firms in Nigeria (A Study of Selected Manufacturing Firms). Journal of Business and Management, vol. 18(10), pp 80-85

[9] Harley E. R. and Emery A. T.(2016), Corporate Financial Control Mechanisms and Firm Performance: The Case of Value-Based Management Systems. Journal of Business Finance and Accounting, 14(12)

[10] Herman E. (2015), The Importance of the Manufacturing Sector in the Romanian Economy. $9^{\text {th }}$ International Conference Interdisciplinary in Engineering, INTER-ENG 2015, 8-9 October 2015, TirguMures, Romania

[11] Hunt, E. K. \& Lautzenheiser, M. (2011). History of Economic Thought: A Critical Perspective. (3rd Ed) New York: M. E. Sharpe

[12] Ibrahim S., Diibuzie G. and Abubakari M. (2017). The Impact of Internal Control Systems on Financial Performance: The Case of Health Institutions in the Upper West Region of Ghana. International Journal of Academic Research in Business and Social Sciences, 7(4)

[13] Ikrama S. \& Ahmed B.,(2018). Risk and Financial Planning Practices in Small and Micro Enterprises: -An Empirical Study. International Research Journal of Commerce, Arts and Science, vol. 9(7) http://www. casiri.com

[14] Kahando D.K., Maina T. M. \& Maina C. M.,(2017). An Appraisal of Financial Management Practices on the Growth of Micro Enterprise in Kenya. Journal of Business and Economic Development, vol. 2(1)pp.63-70,http://www.sciencepublishinggroup.com/j/jbed

[15] Kinyua J. K., Gakure R., Gekara M. \& Orwa G.,(2015). Effect of Internal Control Environment on the Financial Performance of Companies Quoted in the Nairobi Securities Exchange. International Journal of Innovative Finance and Economics Research, Vol. 3(4) pp. 29-46, www.seahipaj.org

[16] Koech C. J. \& Maina K. E.,(2018). Effect of Control Environment on Fraud Detection and Prevention at University of Eldoret, Kenya. Africa International Journal of Management Education and Governance vol. 3(2), pp. 43-51, www.oirjournals.org

[17] Levine, R. (2012). "Financial Development and Economic Growth: Views and Agenda. Journal of Economic Literature, Vol. 35, No. 2, p. 688- 726.

[18] Maiga A., Nilsson A. \& Jacobs F.A.,(2018). Assessing the Interaction Effect of Cost Control Systems and Information Technology Integration on Manufacturing Plant Financial Performance. The British Accounting Review, 1(14), www.elsevier.com/locate/bar

[19] Malik, M., Waseem, J. U., \& Kifayat U. (2011).Working capital management and profitability an analysis of firms of textile industry of Pakistan. Journal of Managerial Sciences, 6(2), 155-165.

[20] McCrindell J.Q. (2015), Framework for Financial Management and Control. Journal of Finance Management Institute, 16(2) pp, 11-39

[21] Mutya T. (2018), Cost Control: A fundamental tool towards Organization Performance. Journal of Accounting \& Marketing, vol. 7(3)

[22] Omboga J. K \& Okibo W, B (2016). Effects of Financial Planning Practices on the Growth of Small Manufacturing Firms in Kishii County, Kenya, International Journal of Economics, Commerce and Management, vol. iv(4), 
[23] Osadchy E. A and Akhmetshin E. A. (2015), Development of the Financial Control System in the Company in Crisis. Mediterranean Journal of Social Sciences, vol. 6, 5(52)

[24] Oyebamiji F.F.,(2018), Materials Management and its Effect on the Performance of Manufacturing Sector: Evidence from Nigerian Cement Industry. South Asian Journal of Social Studies and Economics, vol. 1(4) pp 1-9

[25] Pallant, J. F. (2015): SPSS Survival Manual: A step by step guide to data analysis using SPSS. Allen and Unwin, Australia

[26] Prempeh K. B, (2015), The Impact of Efficient Inventory Management on Profitability: Evidence from Selected Manufacturing Firms in Ghana. MPRA Paper No 67889,

[27] Saunders, M. N. K. et al (2013): Research Methods for Business Students. F T Prentice Hall, Harlow

[28] Sekaran, U. (2011): Research Methods for Business: A Skills Building Approach. John Wiley and Sons Inc., New York

[29] Selvanayaki S., Sivakumar S.D., Rohini A. \& Mani K.(2016), Financial Management Practices and Profitability of Modern Rice Milling Firms in Kagayam Cluster, Tamil Nadu. Agricultural Economics Research Review, vol. 29(2), pp 297-306

[30] Simiyu E.M \& Mainin M.M.,(2018). Budget Monitoring and Financial Performance of Public Sugar Firms in Kenya. International Journals of Academics \& Research. Vol. 1(1),

[31] Siyanbola T.T. and Raji G. M.(2013), The Impact of Cost Control on Manufacturing Industries' Profitability. International Journal of Management and Social Sciences Research, vol.2, 4.

[32] Siyanbola, T. T.(2013), The Impact of Budgeting and Budgetary Control on the Performance of Manufacturing Company In Nigeria. Journal of Business Management \& Social Sciences Research, 2(12)

[33] Uwuigbe, O., Uwalomwa, U., \& Egbide, B. C. (2011). Cash management and corporate profitability: a study of selected listed manufacturing firms in Nigeria. Acta Universitatis Danubius. Oeconomica, 8(1), 49-59.

Citation: Dr. Abbas Umar Ibrahim, Abu Martins Mustapha. "Impact of Financial Control Mechanisms on Profitability Performance: A Case of Manufacturing Firms in Nigeria" International Journal of Managerial Studies and Research (IJMSR), vol 7, no. 3, 2019, pp. 1-10. doi: http://dx.doi.org/10.20431/ 23490349.0703001.

Copyright: (c) 2019 Authors. This is an open-access article distributed under the terms of the Creative Commons Attribution License, which permits unrestricted use, distribution, and reproduction in any medium, provided the original author and source are credited. 